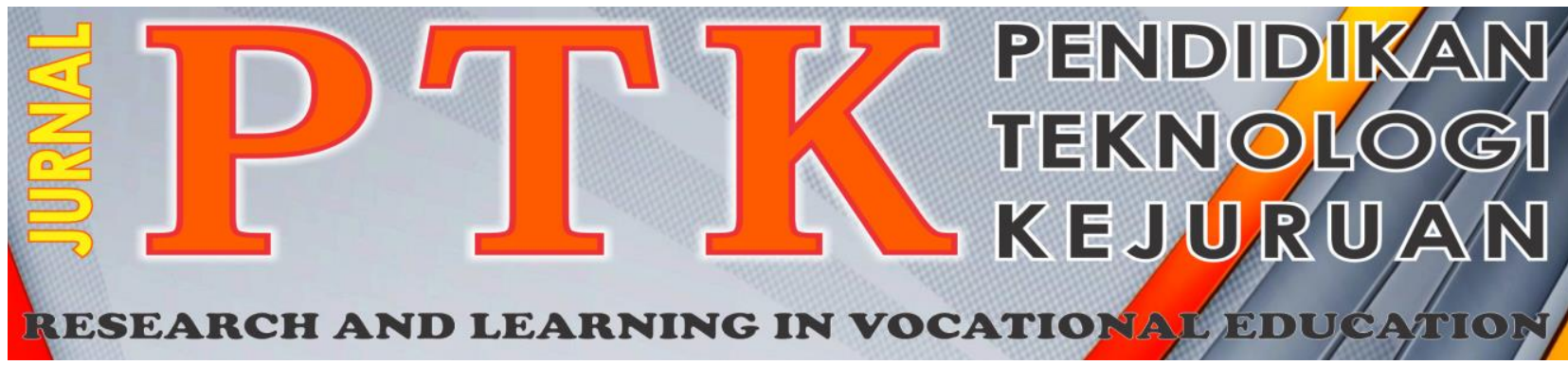

Vol. 2, No. 4, 2019

P-ISSN: 2621-3273

E-ISSN: 2621-1548

\title{
PERBAIKAN SIKAP KERJA UNTUK MENGATASI KELUHAN AKIBAT BEBAN KERJA PADA PROSES PANAS VULKANISIR BAN DI PT. INTI VULKATAMA
}

\author{
Tri Ernita ${ }^{1}$, Gamindra Jauhari ${ }^{2}$. Dwiki Mahendra Yeza ${ }^{3}$ \\ ${ }^{123}$ Program Studi Teknik Industri, Sekolah Tinggi Teknologi Industri Padang \\ Corresponding author e-mail: triernita@sttind.ac.id
}

\begin{abstract}
Abstrak-PT. Inti Vulkatama adalah perusahaan industri manufaktur yang bergerak di bidang vulkanisir ban. Vulkanisir ban adalah salah satu proses daur ulang ban yang sudah gundul melalui beberapa proses dan tahapan seperti inspeksi/pemeriksaan, pemarutan (buffing), knifing, repair, cementing, building, envelope (pada proses dingin), rim dan flange (pemasangan velg), curring (memasukan ban dalam masing-masing cetakan, baik proses panas maupun dingin) dan pemeriksaan akhir. Penilaian berpedoman kepada aspek pekerjaan yang menjadi penilaian sebagai parameter risiko ergonomi berdasarkan tekanan beban yang digunakan, postur tubuh, jenis pergerakan atau aksi, pengulangan posisi tangan saat bersentuhan dengan objek. Penelitian ini bertujuan untuk mendapatkan data bagian tubuh yang lebih berisiko terjadinya musculoskeleteal dan risiko cidera yang dominan terjadi pada pekerja dalam melakukan pekerjaan yang sama dengan menggunakan metode QEC (Quick Expossure Checklist). Setelah dilakukan perhitungan dengan menggunakan lembar exposure score maka bagian tubuh yang mengalami risiko terjadinya musculoskeleteal adalah bagian punggung dan bagian leher. Dalam melakukan pekerjaan, resiko cedera yang dominan terjadi pada dua orang pekerja atau lebih adalah pada action level 4. Yang artinya semua pekerja akan mengalami resiko cedera tingkat tinggi. Hal ini dikarenakan sikap kerja yang di lakukan berulang dan beban kerja yang berat yang di emban oleh pekerja PT. Inti Vulkatama. Karena semakin lama resiko cidera akan semakin tinggi terhadap pekerja.
\end{abstract}

Kata kunci : Sikap Kerja, Ergonomi, QEC

\begin{abstract}
PT. Inti Vulkatama is one of the manufacturing industry companies in the tire vulcanizing sector. Tire vulcanizing is one of the recycling processes for bald tires through several stages, such as inspection, buffing, knifing, repairing, cementing, building, enveloping, rim and flange, curring, and final inspection.Assessment was carried out based on the work aspects assessed as the ergonomic risk parameter which was based on the body posture, the pressure of the load used, the type of the movement or action, and the repetition of the hand positions when having contact with the object. This research aimed to collect the data related to the body parts in which are at risk for having musculoskeletal and the dominant risk of injury on the workers in doing the same work by using the QEC (Quick Exposure Checklist) method. After Calculating using the exposure score sheet, the part of body that are at risk of developing musculoskeleteal are the back and neck with a very high level expossurew. The dominant risk injury to two or more workers is action level 4 wich means that all workers in a high level of injury risk. Based on the results from analyzing the data in the case of work attitude and the workers' complaints which was due to the workloads in tire vulcanizing process, there should be an improvement related to the work attitude in that station which was due to the high risk of injury to the workers. It is because the risk of injury is getting higher.
\end{abstract}

Keywords : Work Attitudes, Ergonomic, QEC

Copyright () 2019 JPTK. All rights reserved

\section{PENDAHULUAN}

PT. Inti Vulkatama merupakan perusahaan industri manufaktur yang bergerak di bidang vulkanisir ban. Vulkanisir ban adalah salah satu proses daur ulang ban yang sudah gundul melalui beberapa proses dan tahapan seperti inspeksi/pemeriksaan, pemarutan (buffing), knifing, repair, cementing, building, envelope (pada proses dingin), rim dan flange (pemasangan velg), curring (memasukan ban dalam masing-masing cetakan, baik proses panas maupun dingin) dan pemeriksaan akhir. PT. Inti Vulkatama sendiri memiliki tiga jenis proses 
produksi yaitu proses panas, proses dingindan OTR (Off The Road).

Berdasarkan hasil studi pendahuluan pada PT. Inti Vulkatama yang memiliki 15 orang pekerja di stasiun proses panasyang sebagian diantaranya mengeluhkan rasa sakit setelah melakukan pekerjaan dikarenakan sikap kerja dan posisi kerjayang belum ergonomi serta peralatan yang digunakan belum mempertimbangkan aspek ergonomi. Berdasarkan pengamatan yang dilakukan secara langsung pada proses pekerjaan, salah satunya yaitu proses pencetakan ban masih dilakukan dengan menggunakan mesin dan manual. Dalam pengerjaannya, beberapa postur kerja dapat menimbulkan resiko karena pekerjaan berulang di stasiun proses panas yaitu stasiun kerja Building, Rim, and Flange dan Pencetakan (curring). Pada stasiun building, stasiun rim, dan stasiun flange, postur tubuh pekerja tidak sama. Dan berdasarkan hal tersebut, dilakukan penelitian yang bertujuan untuk mengetahui tingkat resiko ergonomic dari postur kerja dan perbaikan untuk mengurangi resiko, Metode yang digunakan adalah Quick Exposure Checklist dengan pendekata biomekanika.

\section{METODE}

Penelitian dilaksanakan di PT. Inti Vulkatama Sumatera Barat. Lokasi pabrik dan kantor pusat berada di Jalan Adinegoro, Lubuk Buaya, Padang, Sumatera Barat. Penelitian ini dilaksanakan pada bulan Juni 2019. Populasi dalam penelitian ini adalah pabrik PT. Inti Vulkatama dan sampel pada penelitian ini adalah pekerja pabrik PT. Inti Vulkatama di stasiun proses panas. Teknik Pengambilan Sampel adalah teknik sampling jenuh. Teknik sampling jenuh adalah teknik penentuan sampel dengan menjadikan semua populasi sebagai sampel apabila populasi kurang dari 30 orang.

Untuk mencapai tujuan penelitian, maka penulis menggunakan langkah-langkah sebagai berikut. Untuk enentukan risiko sikap kerja pada proses vulkanisir ban di stasiun proses panas dapat dilakukan perhitungan dengan metode serta menganalisis keluhan yang dialami operator, salah satu metode yang digunakan adalah Quick Exposure Checklist atau yang dsingkat dengan $Q E C$.

$Q E C$ bertujuan untuk mengenali tingkat resiko cedera pada punggung, bahu, leher, dan pergelangan tangan. 3 tahap yang dilakukan dalam menganalisis resiko cedera adalah penilaian dari sudut pandang pengamat, penilaian dari sudut pandang pekerja dan penilaian dari sudut pandang pengamat dan pekerja. Setelah mendapat data hasil dari kuisioner langkah selanjutnya adalah mengkalkulasikan nilai dari jawaban kuesioner pada empat bagian tubuh dari setiap pekerja yang terdiri dari punggung, leher, bahu dan pergelangan tangan sesuai stasiun kerja yang di teliti pada lembar tabel skor penilaian (Exposure Score) QEC guna mengetahui tingkat risiko cidera pada empat bagian tubuh tersebut. Tingkat risiko cedera pada anggota tubuh yang didapatkan berdasarkan nilai expossure score kemudian disesuaikan dengan tabel exposure level guna mengetahui risiko cidera pada anggota tubuh.

Tabel 1. Expossure Level QEC

\begin{tabular}{|l|c|c|c|c|}
\hline \multicolumn{5}{|c|}{ Expossure Level } \\
\hline \multicolumn{1}{|c|}{ Score } & Low & Moderate & High & Very High \\
\hline Punggung (Statis) & $8-15$ & $16-22$ & $23-29$ & $29-45$ \\
\hline Punggung ( Dinamis) & $10-20$ & $21-30$ & $31-40$ & $41-56$ \\
\hline Bahu/Lengan & $10-20$ & $21-30$ & $31-40$ & $41-56$ \\
\hline Pergelangan tangan & $10-20$ & $21-30$ & $31-40$ & $41-56$ \\
\hline Leher & $4-6$ & $8-10$ & $12-14$ & $16-18$ \\
\hline Berkendara & 1 & 4 & 9 & - \\
\hline Getaran & 1 & 4 & 9 & - \\
\hline kecepatan kerja & 1 & 4 & 9 & - \\
\hline Stress & 1 & 4 & 9 & 16 \\
\hline
\end{tabular}

Adapun tahapan penilaian adalah sebagai berikut:

1. Rekapitulasi hasil perhitungan pada tabel skor penilaian expossure score.

2. Menentukan tindakan berdasarkan nilai yang dihasilkan dalam perhitungan exposure level. Menurut Brown dan Li g (2003). Berikut rumus yang digunakan untuk menghitung exposure level:

$$
\mathrm{E}(\%)=\frac{x}{x m a k s} \times 100 \%
$$

Keterangan:

$\mathrm{X}=$ Jumlah Skor yang didapatkan dari penilaian terhadap postur (punggung+bahu/lengan+pergelangan tangan + leher)

$\mathrm{Xmax}=$ Skor maksimum untuk postur kerja (punggung+bahu/lengan+pergelangan tangan+leher)

Xmax disebut keadaan konstan untuk beberapa pekerjaan tertentu. Pada saat tubuh dalam keadaan statis seperti duduk atau berdiri, diberikan skor Xmax $=162$. Apabila keadaan tubuh membawa beban, mendorong, menarik, mengangkat atau disebut dalam keadaan tidak statis maka diberikan skor Xmax $=$ 176. Tindakan yang dilakukan berdasarkan perhitungan, dituangkan dalam perhitungan sebagai berikut:

Tabel 2. Action Level QEC berdasarkan total skor

\begin{tabular}{|c|c|c|}
\hline Jumlah Skor & Action Level & Penanganan \\
\hline$<70$ & Action Level 1 & Nilai tersebut dapat diterima \\
\hline $70-88$ & Action Level 2 & Investigasi Lebih Lanjut \\
\hline $89-123$ & Action Level 3 & $\begin{array}{c}\text { Investigasi Lebih Lanjut dan penanganan } \\
\text { dalam waktu dekat }\end{array}$ \\
\hline$<123$ & Action Level 4 & $\begin{array}{c}\text { Investigasi lebih lanjut dan dilakukan } \\
\text { penanganan secepatnya }\end{array}$ \\
\hline
\end{tabular}

Jurnal PTK: Research and Learning in Vocational Education 
Tindakan yang harus dilakukan berdasarkan persentase yang dihasilkan dalam perhitungan dituangkan dalam tabel berikut:

Tabel 3. Action Level QEC berdasarkan tingkat persentase

\begin{tabular}{|c|c|}
\hline Total Expossure Level & Penanganan \\
\hline$<40 \%$ & Nilai tersebut dapat diterima \\
\hline $40-49 \%$ & Investigasi Lebih Lanjut \\
\hline $50-59 \%$ & $\begin{array}{c}\text { Investigasi Lebih Lanjut dan penanganan } \\
\text { dalam waktu dekat }\end{array}$ \\
\hline $70 \%$ & $\begin{array}{c}\text { Investigasi lebih lanjut dan dilakukan } \\
\text { penanganan secepatnya }\end{array}$ \\
\hline
\end{tabular}

\section{HASIL DAN PEMBAHASAN}

Berikut rekapitulasi jawaban kuisioner observer.

Tabel 4. Jawaban Kuisioner

\begin{tabular}{|c|c|c|c|c|c|c|c|c|c|}
\hline \multirow{2}{*}{ Stasiun Kerja } & \multirow{2}{*}{ Operator } & \multirow{2}{*}{ Nama Operator } & \multicolumn{2}{|c|}{ Punggung } & \multicolumn{2}{|c|}{ BahuLengan } & \multicolumn{2}{|c|}{ Pergelangan Tangan } & \multirow{2}{*}{ Leher } \\
\hline & & & 1 & 2 & 1 & 2 & 1 & 2 & \\
\hline Inspeksi & 1 & Edi Sofyan & $\mathrm{A} 3$ & B3 & $\mathrm{C} 2$ & D3 & E2 & F2 & G3 \\
\hline \multirow{2}{*}{ Pemarutan (Buffing) } & 1 & Alhamra & $\mathrm{Al}$ & B3 & $\mathrm{C} 2$ & D3 & E2 & F3 & G2 \\
\hline & 2 & Hermansyah & $\mathrm{Al}$ & B3 & $\mathrm{C} 2$ & D3 & E2 & $\mathrm{F} 2$ & G2 \\
\hline \multirow{2}{*}{$\begin{array}{l}\text { Kniffing (sisip } \\
\text { gerinda/brush) }\end{array}$} & 1 & Anovari & $\mathrm{A} 3$ & B3 & $\mathrm{C} 3$ & D3 & E2 & F3 & G3 \\
\hline & 2 & Syamsul Bahri & $\mathrm{A} 2$ & B3 & $\mathrm{C} 2$ & D3 & E2 & $\mathrm{Fl}$ & G2 \\
\hline Repair/Cord & 1 & Heriyanto & $\mathrm{A} 3$ & B3 & $\mathrm{Cl}$ & D3 & E2 & F3 & G3 \\
\hline Cementing & 1 & Soeyono & $\mathrm{A} 2$ & B1 & $\mathrm{C} 3$ & D3 & E2 & F3 & $\mathrm{Gl}$ \\
\hline \multirow{2}{*}{ Sisip Gum (Filling) } & 1 & Zulkifli & $\mathrm{A} 2$ & B3 & $\mathrm{C} 2$ & D3 & E2 & F2 & G2 \\
\hline & 2 & Indra Putra & $\mathrm{A} 2$ & $\mathrm{~B} 3$ & $\mathrm{C} 2$ & D3 & E2 & $\mathrm{F} 2$ & G2 \\
\hline \multirow{2}{*}{ Building } & 1 & Yusman Phil & $\mathrm{A} 3$ & B3 & $\mathrm{C} 2$ & D3 & $\mathrm{E} 2$ & F2 & C3 \\
\hline & 2 & Joni Firdaus & $\mathrm{A} 3$ & B3 & $\mathrm{C} 2$ & D3 & E2 & $\mathrm{F} 2$ & G3 \\
\hline \multirow{2}{*}{\begin{tabular}{|c} 
Pemasangan velg dan ban \\
dalam (Rim and Flange)
\end{tabular}} & 1 & Yossizal & $\mathrm{A3}$ & B3 & $\mathrm{Cl}$ & D3 & E2 & F3 & G3 \\
\hline & 2 & Renaldi & $\mathrm{A} 3$ & B3 & $\mathrm{Cl}$ & D3 & E2 & F3 & $\mathrm{G} 33$ \\
\hline \multirow{2}{*}{ Pencetakan (Curring) } & 1 & Syafrudin & $\mathrm{A3}$ & B3 & $\mathrm{C3}$ & D3 & E2 & F3 & G3 \\
\hline & 2 & Iswandi & $\mathrm{A} 3$ & $\mathrm{~B} 3$ & $\mathrm{C} 3$ & D3 & $\mathrm{E} 2$ & F3 & $\mathrm{G} 3$ \\
\hline
\end{tabular}

Berikut rekapitulasi kuisioner jawaban pekerja

Tabel 5. Rekapitulasi Kuesioner Worker

\begin{tabular}{|c|c|c|c|c|c|c|c|c|c|c|}
\hline \multirow{2}{*}{ Stasiun Kerja } & \multirow{2}{*}{ Operator } & \multirow{2}{*}{ Nama Operator } & \multicolumn{7}{|c|}{ Pertanyaan } & \multirow[b]{2}{*}{0} \\
\hline & & & $\mathrm{H}$ & I & $\mathrm{J}$ & $\mathrm{K}$ & $\mathrm{L}$ & M & $\mathrm{N}$ & \\
\hline Inspeksi & 1 & Edi Sofyan & $\mathrm{H} 2$ & 13 & $\mathrm{~J} 2$ & $\mathrm{~K} 2$ & $\mathrm{Ll}$ & $\mathrm{M} 3$ & $\mathrm{~N} 2$ & 01 \\
\hline \multirow{2}{*}{ Pemarutan (Buffing) } & 1 & Alhamra & $\mathrm{H} 2$ & 12 & $\mathrm{~J} 3$ & $\mathrm{~K} 2$ & $\mathrm{Ll}$ & $\mathrm{M} 2$ & $\mathrm{~N} 2$ & 01 \\
\hline & 2 & Hermansyah & $\mathrm{H} 3$ & 12 & $\mathrm{J3}$ & $\mathrm{K} 2$ & $\mathrm{Ll}$ & $\mathrm{M} 2$ & $\mathrm{~N} 2$ & 01 \\
\hline \multirow{2}{*}{$\begin{array}{l}\text { Kiffing (sisip } \\
\text { gerindalorush) }\end{array}$} & 1 & Anovari & $\mathrm{H} 3$ & 12 & $\mathrm{J3}$ & K2 & $\mathrm{LI}$ & M2 & $\mathrm{N} 2$ & 01 \\
\hline & 1 & Syamsul Bahri & $\mathrm{H} 3$ & 13 & $\mathrm{~J} 3$ & $\mathrm{~K} 1$ & $\mathrm{Ll}$ & $\mathrm{Ml}$ & $\mathrm{Nl}$ & 01 \\
\hline Repair/Cord & 1 & Heriyanto & $\mathrm{H} 2$ & 13 & $\mathrm{~J} 2$ & K2 & L3 & $\mathrm{M} 2$ & $\mathrm{~N} 2$ & 02 \\
\hline Cementing & 1 & Soeyono & $\mathrm{H} 2$ & 13 & $\mathrm{~J} 2$ & $\mathrm{~K} 2$ & $\mathrm{LI}$ & $\mathrm{M} 2$ & $\mathrm{~N} 2$ & 01 \\
\hline \multirow{2}{*}{ Sisip Gum (Filling) } & 1 & Zulkifili & $\mathrm{H} 3$ & 13 & $\mathrm{~J} 3$ & $\mathrm{~K} 2$ & $\mathrm{Ll}$ & $\mathrm{Ml}$ & $\mathrm{N} 2$ & 01 \\
\hline & 2 & Indra Putra & $\mathrm{H} 3$ & 13 & $\mathrm{J3}$ & K2 & $\mathrm{Ll}$ & $\mathrm{Ml}$ & $\mathrm{N} 2$ & 01 \\
\hline \multirow{2}{*}{ Building } & 1 & Yusman Phil & $\mathrm{H} 3$ & 13 & $\mathrm{~J} 3$ & $\mathrm{~K} 1$ & $\mathrm{Ll}$ & $\mathrm{M} 3$ & N2 & 02 \\
\hline & 2 & $\begin{array}{l}\text { Joni Frdaus } \\
\end{array}$ & $\mathrm{H} 3$ & 13 & $\mathrm{~J} 3$ & $\mathrm{KI}$ & $\mathrm{Ll}$ & $\mathrm{Ml}$ & $\mathrm{N} 2$ & 01 \\
\hline \multirow{2}{*}{$\begin{array}{l}\text { Pemasangan velg dan ban } \\
\text { dalam (Rim and Flange) }\end{array}$} & 1 & Yosizal & $\mathrm{H} 3$ & 13 & $\mathrm{J3}$ & $\mathrm{K} 1$ & $\mathrm{Ll}$ & $\mathrm{M} 3$ & $\mathrm{~N} 3$ & 02 \\
\hline & 2 & Renaldi & $\mathrm{H} 3$ & 13 & $\mathrm{J3}$ & K2 & $\mathrm{LI}$ & $\mathrm{M} 3$ & $\mathrm{~N} 2$ & 01 \\
\hline \multirow{2}{*}{ Pencetakan (Curring) } & 1 & Syafrudin & $\mathrm{H} 3$ & I3 & $\mathrm{J} 3$ & $\mathrm{~K} 1$ & $\mathrm{Ll}$ & $\mathrm{M} 3$ & $\mathrm{~N} 3$ & 02 \\
\hline & 2 & Iswandi & $\mathrm{H} 3$ & 13 & $\mathrm{~J} 3$ & $\mathrm{~K} 1$ & $\mathrm{Ll}$ & $\mathrm{M} 3$ & $\mathrm{~N} 3$ & 03 \\
\hline
\end{tabular}

Berdasarkan hasil rekapitulasi jawaban kuisioner operator dan pengamat operator pada stasiun kerja, kemudian dilakukan perhitungan nilai exposure score pada punggung, bahu atau lengan atas, pergelangan tangan, dan leher dengan mempertimbangkan kombinasi atau interaksi, gaya atau beban, postur dengan durasi, dan pergerakan dengan durasi. Berikut lembar perhitungan exposure score dari jawaban kuisioner operator dan pengamat operator pada stasiun inspeksi.

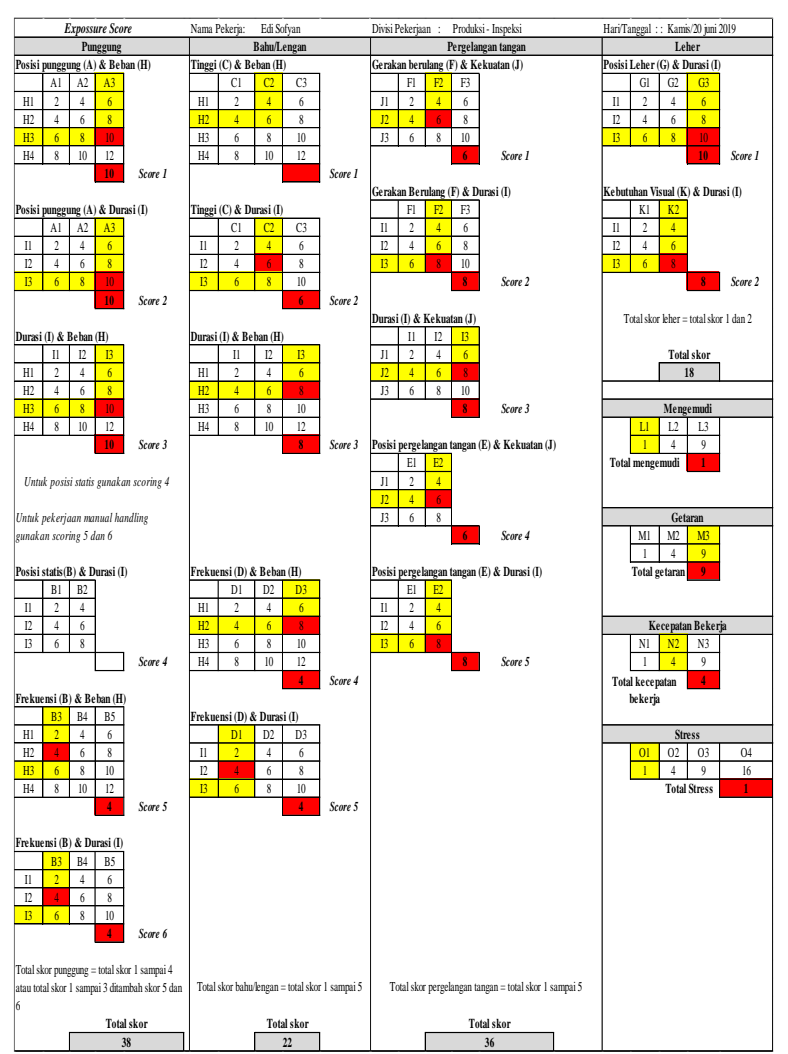

Gambar 1. Expossure ScoreOperator Stasiun Inspeksi

Setelah mendapat hasil dari Lembar Expossure Score langkah selanjutnya adalah merekap nilai Expossure Score pada bagian punggung, leher, bahu dan pergelangan tangan. serta faktor lainnya seperti getaran, durasi dan tingkat stress saat bekerja sesuai operator per stasiun kerja yang di teliti guna mengetahui tingkat risiko cidera pada empat bagian tubuh tersebut. Hasil rekapitulasi perhitungan pada lembar exposure score di PT. Inti Vulkatama dapat dilihat pada tabel berikut:

Tabel 6. Rekapitulasi Nilai Exposure Score berdasarkan anggota tubuh

\begin{tabular}{|c|c|c|c|c|c|c|c|c|c|c|c|c|c|c|c|}
\hline \multirow{3}{*}{$\begin{array}{l}\text { Anggota Tubuh } \\
\text { yang Diamati }\end{array}$} & \multicolumn{15}{|c|}{ Nilai Expossure Score di Stasiun Kerja } \\
\hline & \multirow{2}{*}{\begin{tabular}{|c|} 
Inspeksi \\
$0 \mathrm{P}$
\end{tabular}} & \multicolumn{2}{|c|}{ Buffing } & \multicolumn{2}{|c|}{ Kniffing } & \multirow{2}{*}{\begin{tabular}{|c|} 
Repair \\
OP
\end{tabular}} & \multirow{2}{*}{$\begin{array}{c}\text { Cementing } \\
0 P\end{array}$} & \multicolumn{2}{|c|}{\begin{tabular}{|l|} 
Filling \\
\end{tabular}} & \multicolumn{4}{|c|}{ Building Rim and Flange } & \multicolumn{2}{|c|}{ Curring } \\
\hline & & $0 \mathrm{Pl}$ & OP2 & OP1 & OP2 & & & OP1 & OP2 & OP1 & OP2 & OP1 & OP2 & & OP2 \\
\hline Punggung (Statis) & - & - & $\cdot$ & - & $\cdot$ & - & 22 & - & $\cdot-$ & $\cdot$ & - & - & $\cdot$ & - & - \\
\hline Punggung (Dinamis) & 38 & 28 & 36 & 36 & 38 & 36 & & 44 & 44 & 42 & 42 & 42 & 42 & 42 & 42 \\
\hline BahulLengan & 22 & 28 & 32 & 32 & 36 & 28 & 38 & 38 & 38 & 38 & 38 & 34 & 34 & 38 & 38 \\
\hline Pergelangan tangan & 36 & 30 & 36 & 40 & 34 & 40 & 40 & 40 & 40 & 42 & 42 & 46 & 46 & 46 & 46 \\
\hline Leher & 18 & 12 & 12 & 14 & 14 & 18 & 16 & 16 & 16 & 18 & 18 & 18 & 18 & 16 & 16 \\
\hline mengendarai & 1 & 9 & 1 & 1 & 1 & 9 & 1 & 1 & 1 & 1 & 1 & 1 & 1 & 1 & 1 \\
\hline getaran & 9 & 4 & 4 & 4 & 1 & 4 & 1 & 1 & 1 & 9 & 9 & 9 & 9 & 9 & 9 \\
\hline kecepatan kerja & 4 & 4 & 4 & 4 & 1 & 4 & 4 & 4 & 4 & 4 & 4 & 4 & 4 & 9 & 9 \\
\hline Faktor stress & 1 & 1 & 1 & 1 & 1 & 4 & 1 & 1 & 1 & 4 & 1 & 4 & 1 & 4 & 9 \\
\hline
\end{tabular}

Setelah diperoleh nilai total exposure score masing-masing anggota tubuh operator di stasiun proses panas, selanjutnya di rekap dan di kelompokan berdasarkan exposure level. Rekapitulasi nilai exposure score berdasarkan 
exposure level masing-masing operator per stasiun kerja adalah sebagai berikut:

Tabel 7. Rekapitulasi Nilai Expossure Score Berdasarkan Expossure Level

\begin{tabular}{|c|c|c|c|c|c|c|c|}
\hline \multirow{3}{*}{$\begin{array}{c}\text { Anggota } \\
\text { Tubuh yang } \\
\text { Diamati }\end{array}$} & \multicolumn{7}{|c|}{ Expossure Level di Stasiun Kerja } \\
\hline & \multirow{2}{*}{\begin{tabular}{|c|} 
Inspeksi \\
OP \\
\end{tabular}} & \multicolumn{2}{|c|}{ Buffing } & \multicolumn{2}{|c|}{ Kniffing } & \multirow{2}{*}{$\begin{array}{c}\text { Repair } \\
\text { OP }\end{array}$} & \multirow{2}{*}{\begin{tabular}{|c|} 
Cementin \\
OP
\end{tabular}} \\
\hline & & OP1 & OP2 & OP1 & OP2 & & \\
\hline $\begin{array}{c}\text { Punggung } \\
\text { (Statis) }\end{array}$ & - & - & - & - & - & - & Moderate \\
\hline & Very High & High & Very High & Very High & Very High & Very High & - \\
\hline Bahu/Le & & & & & & Moderate & $\mathrm{High}$ \\
\hline $\begin{array}{c}\text { Pergelanga } \\
\text { tangan }\end{array}$ & Very High & Very High & High & High & High & High & High \\
\hline Leher & & & High & $\mathrm{High}$ & High & Very High & Very Hig \\
\hline mengendarai & & High & Low & Low & Low & High & Low \\
\hline & & Moderate & Moderate & Moder & & $\mathrm{High}$ & Low \\
\hline ecepatan $\mathrm{k}$ & Moderate & Moderate & Moderate & Moderate & & High & Modera \\
\hline Faktor str & Low & Low & Low & Moderate & Low & High & Low \\
\hline
\end{tabular}

Berdasarkan hasil pengolahan data, tubuh bagian punggung, leher, dan pergelangan tangan memiliki risiko paling tinggi terjadinya muscoluskeleteal hal ini dapat dilihat pada hasil rekapitulasi nilai exposure score berdasarkan exposure level pada 15 Pekerja dan 5 bagian tubuh yang diamati serta 4 faktor lainnya lainnya seperti getaran, berkendara, kecepatan kerja dan faktor stres. Rekapitulasi Total nilai exposure score adalah sebagai berikut:

Tabel 8. Rekapitulasi Total Nilai Expossure Score

\begin{tabular}{|c|c|c|}
\hline \multicolumn{2}{|c|}{ Stasiun Kerja } & $\begin{array}{c}\text { Total Nilai } \\
\text { Expossure Score }\end{array}$ \\
\hline Inspeksi (Dinamis) & & 129 \\
\hline \multirow{2}{*}{ Buffing (Dinamis) } & OP 1 & 116 \\
\cline { 2 - 3 } Kniffing (Dinamis) & OP 2 & 126 \\
\cline { 2 - 3 } & OP 1 & 132 \\
\hline OP 2 & 126 \\
\hline Cepair (Dinamis) & & 143 \\
\hline \multirow{2}{*}{ Filling (Dinamis) } & OP 1 & 123 \\
\cline { 2 - 3 } Building (Dinamis) & OP 2 & 145 \\
\cline { 2 - 3 } & OP 1 & 158 \\
\hline Rim and Flange & OP 2 & 155 \\
\cline { 2 - 3 } (Dinamis) & OP 1 & 158 \\
\hline \multirow{2}{*}{ OP 2} & 155 \\
\hline \multirow{2}{*}{ Rurring (Dinamis) } & OP 1 & 165 \\
\cline { 2 - 3 } & OP 1 & 170 \\
\hline \multirow{2}{*}{ Rata - rata } & $\mathbf{1 4 3 . 0 6 6 6 6 6 7}$ \\
\hline
\end{tabular}

Total nilai exposure score didapat dari hasil penjumlahan (faktor stress + kecepatan kerja + getaran + mengendarai + leher + Pergelangan tangan + punggung + bahu atau lengan). Setelah melakukan rekapitulasi exposure score, dilanjutkan dengan menentukan tindakan berdasarkan nilai yang didapatkan dalam perhitungan exposure level. Berikut adalah contoh perhitungan untuk operator di stasiun inspeksi.

$$
\begin{gathered}
E(\%)=\frac{x}{X \max } \times 100 \% \\
E(\%)=\frac{129}{176} \times 100 \% \\
=73,30 \%
\end{gathered}
$$

Pada operator di stasiun inspeksi memiliki total nilai expossure score sebesar 129 hal ini membutuhkan penangan investigasi lebih lanjut serta penanganan secepatnya. dan nilai exposure leve $l$ sebesar $73,30 \%$. Berikut jumlah skor dan penangan

\begin{tabular}{|c|c|c|c|c|c|}
\hline \multicolumn{2}{|c|}{ Stasiun Kerja } & \multirow{2}{*}{\begin{tabular}{|c}
$\begin{array}{c}\text { Total Nilai } \\
\text { Expossure Score }\end{array}$ \\
129
\end{tabular}} & \multirow{2}{*}{$\begin{array}{c}\begin{array}{c}\text { Expossure } \\
\text { Level E (\%) }\end{array} \\
73.30 \%\end{array}$} & \multirow{2}{*}{\begin{tabular}{|l} 
Action Level \\
Action Level 4
\end{tabular}} & \multirow{2}{*}{\begin{tabular}{|c|} 
Penanganan \\
$\begin{array}{c}\text { Investigasi lebih lanjut } \\
\text { dan dilakukan } \\
\text { penanganan secepatny }\end{array}$ \\
\end{tabular}} \\
\hline Inspeksi (Dinamis) & & & & & \\
\hline \multirow{2}{*}{ Buffing (Dinamis) } & OP 1 & 116 & $65.91 \%$ & Action Level 3 & $\begin{array}{c}\text { Investigasi Lebih Lanjut } \\
\text { dan penanganan dalam } \\
\text { waktu dekat }\end{array}$ \\
\hline & OP 2 & 126 & $71.59 \%$ & Action Level 4 & $\begin{array}{c}\text { Investigasi lebih lanjut } \\
\text { dan dilakukan } \\
\text { penanganan secepatnya }\end{array}$ \\
\hline \multirow[t]{2}{*}{ Kniffing (Dinamis) } & OP 1 & 132 & $75.00 \%$ & Action Level 4 & $\begin{array}{c}\text { Investigasi lebih lanjut } \\
\text { dan dilakukan } \\
\text { penanganan secepatnya }\end{array}$ \\
\hline & $\mathrm{OP} 2$ & 126 & $71.59 \%$ & Action Level 4 & $\begin{array}{c}\text { Investigasi lebih lanjut } \\
\text { dan dilakukan } \\
\text { penanganan secepatnya }\end{array}$ \\
\hline Repair (Dinamis) & & 143 & $81.25 \%$ & Action Level 4 & $\begin{array}{c}\text { Investigasi lebih lanjut } \\
\text { dan dilakukan } \\
\text { penanganan secepatnya }\end{array}$ \\
\hline Cementing (Statis) & & 123 & $75.93 \%$ & Action Level 4 & $\begin{array}{c}\text { Investigasi lebih lanjut } \\
\text { dan dilakukan } \\
\text { penanganan secepatnya }\end{array}$ \\
\hline \multirow{2}{*}{ Filling (Dinamis) } & OP 1 & 145 & $82.39 \%$ & Action Level 4 & \begin{tabular}{|c|} 
Investigasi lebih lanjut \\
dan dilakukan \\
penanganan secepatnya
\end{tabular} \\
\hline & OP 2 & 145 & $82.39 \%$ & Action Level 4 & $\begin{array}{c}\text { Investigasi lebih lanjut } \\
\text { dan dilakukan } \\
\text { penanganan secepatnya }\end{array}$ \\
\hline \multirow{2}{*}{ Building (Dinamis) } & OP 1 & 158 & $89.77 \%$ & Action Level 4 & \begin{tabular}{|c|} 
Investigasi lebih lanjut \\
dan dilakukan \\
penanganan secepatnya
\end{tabular} \\
\hline & OP 2 & 155 & $88.07 \%$ & Action Level 4 & \begin{tabular}{|c}
$\begin{array}{c}\text { Investigasi lebih lanjut } \\
\text { dan dilakukan } \\
\text { penanganan secepatnya }\end{array}$ \\
\end{tabular} \\
\hline \multirow{2}{*}{$\begin{array}{c}\text { Rim and Flange } \\
\text { (Dinamis) }\end{array}$} & OP 1 & 158 & $89.77 \%$ & Action Level 4 & $\begin{array}{c}\text { Investigasi lebih lanjut } \\
\text { dan dilakukan } \\
\text { penanganan secepatnya }\end{array}$ \\
\hline & OP 2 & 155 & $88.07 \%$ & Action Level 4 & $\begin{array}{l}\text { Investigasi lebih lanjut } \\
\text { dan dilakukan } \\
\text { penanganan secepatnya }\end{array}$ \\
\hline \multirow{2}{*}{ Curring (Dinamis) } & OP 1 & 165 & $93.75 \%$ & Action Level 4 & $\begin{array}{c}\text { Investigasi lebih lanjut } \\
\text { dan dilakukan } \\
\text { penanganan secepatnya }\end{array}$ \\
\hline & OP 1 & 170 & $96.59 \%$ & Action Level 4 & $\begin{array}{c}\text { Investigasi lebih lanjut } \\
\text { dan dilakukan } \\
\text { penanganan secepatnya }\end{array}$ \\
\hline \multicolumn{2}{|l|}{ Rata-rata } & 143.0666667 & $81.69 \%$ & & \\
\hline
\end{tabular}
yang dilakukan untuk pekerja di stasiun proses panas.

Tabel 9. Rekapitulasi Skor QEC

Dari perhitungan exposure level, pekerja yang bekerja pada proses panas memiliki:

1. Nilai Exposure level rata-rata berada pada range $\geq$ $70 \%$ yang artinya dalam penanganannya di butuhkan investigasi lebih lanjut dalam hal perbaikan sikap kerja guna mengatasi keluhan akibat beban kerja.

2. Memiliki action level 4 yang artinya dalam penanganannya dibutuhkan investigasi lebih lanjut dalam hal perbaikan sikap kerja guna mengatasi keluhan akibat beban kerja. Penelitian lebih lanjut diperlukan untuk penanganan yang lebih optimal pada stasiun kerja. Dari hasil perhitungan exposure score. Dapat disimpulkan nilai untuk leher punggung berada pada level very high yang berarti risiko terjadinya cidera sangat tinggi. 


\section{KESIMPULAN}

Setelah dilakukan perhitungan dengan menggunakan lembar exposure score maka bagian tubuh yang mengalami risiko terjadinya musculos keleteal adalah tubuh bagian punggung dan leher dengan tingkat exposure level very high. Dalam melakukan pekerjaan yang sama, resiko cedera yang dominan terjadi pada dua orang pekerjaan tau lebih adalah pada action level 4. Yang artinya semua pekerjaakan mengalamir esiko cedera tingkat tinggi. Hal ini dikarenakan sikap kerja yang di lakukan berulang dan beban kerja yang berat yang di emban oleh pekerja PT. Inti Vulkatama.

\section{DAFTAR PUSTAKA}

[1] Andriani, Identifikasi Postur Kerja Secara Ergonomi Untuk Menghindari Musculos keletal Disorder, Universitas Samudra, Aceh, 2017.

[2] Andriani, Meri., Perbaikan Sikap Kerja Untuk Mengatasi beban Kerja, Universitas Samudra, Aceh, 2018

[3] Ahmad,Ilman., Yuniar, Perbaikan Sistem Kerja dengan metode Quick Expossure Check di bengkel sepatu $\mathbf{X}$ Cibaduyut, Institut Teknologi Nasional, Bandung, 2013. Jurnal Online Institut Teknologi Nasional, Vol.01, No.2

[4] Bernard, Bruce P. Musculoskeletal Disorder AND WORKPLACE Factor: A critical Review of Epidemiologic Evidence for Work-Related Musculoskeletal Disorder of The neck, Upper Extrimity, and low Back. U.S Departemen of Health and Human Service: NIOSH

[5] Bird, Frank, E. Jr and L. Germain., Kepemimpinan Pengendalian dan Kerugian Praktis, Edisi ke-3, PT. Rineka Cipta, Jakarta,2005.

[6] Bridger, R.S Introduction to Ergonomic, . Edisi ke-2, Taylor \& Francis, London, 2003.

[7] Brown R., Li G, The Development Of Action Level for The Quick Expossure Checklist (QEC) System, In Contemporary Ergonomics, London, 2003.

[8] Budiono, Sugeng et al. Bunga Rampai Hiperkes dan Keselamatan Kerja: Hygiene Perusahaan, Ergonomik, Keselamatan dan Kesehatan Kerja, Edisi ke-2, Badan Penerbit Undip, Semarang, 2003.

[9] Chain, Review of The Mental Workload Literature. Defence Research and Development Canada Toronro. Human System Integration Section : Canada, 2017

[10] Chapanis, Human Engineering, In The New Encyclopedia Britanica, (Vol.21),(15 ${ }^{\text {th }}$ ed.),(pp $227-$ 229), Encyclopedia Britanica, Chicago, 1985.

[11] Corlett, Alexander 1, Element of Ergonomics Programs, A Primer Based on Workplace Evaluation, U.S Dept. of Health and Human Service: NIOSH, USA, 1998.
[12] Ervil Riko. dkk. Buku Pedoman Penulisan Laporan Kerja Praktik dan Tugas Akhir. STTIND Padang, Padang, 2019.

[13] Ghoper, D., Doncin, Handook of Perception and Human Performance. University of South Dakota. 1986

[14] Hadler, N., Occupational Musculos keleteal Disorders, Lippincott William, North Caroline, 2005.

[15] Hummantech, Applied Ergonomics Training Manual, edisi ke - 2, Australia: Barkelery Vale, 2004

[16] Hignett, Sue, and McAttammey Lynn,Applied Ergonomics: Rapid Entire Body Assessment, CRC Press, USA, 2000.

[17] International Ergonomist Association (IEA), Ergonomics For Childrenand Educational Environment, IEA Congress, Seoul Korea Education for Children in Ergonomics Technical Comite, 2003.

[18] Kurniawati. Tinjauan Faktor Risiko Ergonomi dan Keluhan Subjektif Terhadap Terjadinya Risiko Terjadinya Muskulos keletal Disorders (Msds) Pada Pekerja Pabrik Proses Inspeksi Kain, Pembungkusan, dan Pengepakan di Departemen PPC PT SCTI Ciracas Jakarta Timur. Jurnal, Fakultas Kesehatan Masyarakat Universitas Indonesia, Depok. 2009.

[19] Levy AndWegman, Occupational Health : Recognizing and Preventing Work - Related Disase and Injury, $4^{\text {th }}$ Edition, Lippincott Williams and Wikins, Philadelpia, 2000.

[20] LaDao, J. Occupational Health and Safety $2^{\text {nd }}$ Edition, National Safety Councill Illionist, 2004.

[21] Li g. And Buckle, Further Development Of The Usability and Valibility of The Quick Exposure Check (QEC), http://www.hse.gov.uk/research/crr.

[22] Nofirza, Suci Anisa H., Usulan Perbaikan Postur dan Fasilitas Kerja Menggunakan Plibel Checklist dan Quick Expossure Check (QEC) UIN Suska Riau, 2016.

[23] Nurmianto, Konsep Ergonomi dan Aplikasinya. Guna Widya, Jakarta, 2003. Occupational Health and Safety Council of Ontario (OHSCO), Prevention Musculos Keleteal Tool Box, Ontario USA, 2007

[24] O'Donnell, Eggemeier, Workload Assesment Methodology, Wiley, New York, 1986.

[25] Rezia, Adha, Ezi, Usulan Perbaikan Stasiun Kerja pada PT. Sinar Advertama Servic indo (SAS) Berdasarkan Hasil evaluasai Menggunakan Metode Quick Expossure Check di bengkel sepatu X Cibaduyut, Institut Teknologi Nasional, Bandung, 2014. Jurnal Online Institut Teknologi Nasional, Vol.4, No.02

[26] Santoso, Ergonomi: Manusia, Peralatan dan Lingkungan. Prestasi Pustaka Publisher, Jakarta, 2004.

[27] Sutalaksana, Iftikar, Teknik Tata Cara Kerja, Laboratorium Tata Cara Kerja \& Ergonomi, Departemen Teknik Industri ITB, Bandung, 2006. 
[28] Sugiyono, Metodologi Penelitian Kualitatif, kuantitatif, dan R\&D, Alfabeta, Bandung, 2013

[29] Tarwaka, et al., Ergonomi untuk Kesehatan, Keselamatan, dan Produktifitas, Edisi I. UNIBA Press, Surakarta, 2004.

[30] Triawan, Rudal, Gambaran Tingkat Risiko MSDs pada aktivitas kerja di Bagian Pabrikasi Machine and Gear Shop PT. Bukaka Teknik Utama berdasarkan Metode REBA Fakultas Kesehatan Masyarakat, Universitas Indonesia, Depok, 2007.

[31] Wignjosoebroto, Pengantar Teknik dan Manajemen Industri, Guna Widya, Jakarta, 2003. 